\title{
Visões da AmÉrica latina em Cabezas CORTADAS, DE GLAUbER ROCHA
}

\author{
Estevão Garcia
}

\begin{abstract}
Resumo
Cabezas cortadas, de Glauber Rocha, narra a experiência de um ditador latino-americano em seu exílio espanhol (ainda que o nome do país nunca seja mencionado) e se fundamenta em termos estilísticos por meio de uma operação surrealista de associação de conceitos e símbolos. Essa ferramenta, a operação surrealista na articulação de conceitos e símbolos, constitui o método para a construção do diálogo cultural entre América Latina e Espanha proposto pelo filme. Este artigo apresenta como objetivo, portanto, analisar o diálogo cultural articulado entre Cabezas cortadas e a América hispânica e a sua ideia de identidade latino-americana.
\end{abstract}

\author{
PaLAVRAS-Chave
}

Glauber Rocha; Cabezas cortadas; América Latina; identidade

\section{Visions of Latin America in Glauber ROCHA'S CABEZAS CORTADAS}

\begin{abstract}
Glauber Rocha Cabezas cortadas, narrates the experiences of a Latin-American dictator in his Spanish exile (even though the name of the country is never mentioned) and it grounds itself in stylistic terms by means of a surrealist operation on the association of concepts and symbols. This tool, the surrealist operation on the association of concepts and symbols, constitutes the method for the construction of cultural dialogue between Latin America and Spain set by the film. Therefore, this article presents as a goal to analyze the cultural dialogue between Cabezas cortadas and the Hispanic America and its idea of Latin-American identity.
\end{abstract}

\section{KEYWORDS}

Glauber Rocha; Cabezas cortadas; Latin America; identity

\section{INTRODUÇÃo}

Em 1970, Glauber Rocha (1939-1981) começa a realizar filmes fora do Brasil, porém, antes de se exilar não deixou de ter alguns problemas com o regime militar: tinha sido detido ao lado de sete amigos em 1965, presenciou a proibição de Terra em transe em 1967 e nesse mesmo ano seu apartamento foi invadido pela polícia (Bentes, 1997). Em 1969, depois de obter o prêmio de melhor direção por O dragão da maldade contra o santo guerreiro no Festival de Cannes, recebe duas propostas de trabalho. A primeira 
veio de Claude-Antoine, co-produtor francês de seu último filme; se tratava de um projeto franco-italiano que seria filmado no Congo: Der leone have sept cabeças/ O leão de sete cabeças. A segunda proposta lhe foi oferecida pelo produtor espanhol Pere Fages, que o convida a fazer um filme na Espanha com total liberdade e com um orçamento de 100 mil dólares (Torres, 1970, p. 68). Esse filme se chamará Cabezas cortadas. Esta é a fase mais produtiva da carreira de Glauber, já que dirige dois filmes em menos de um ano e se insere no mercado internacional do cinema de autor. No transcurso desses dois filmes realizados em 1970, o cineasta percebe a impossibilidade de continuar no Brasil o projeto de cinema iniciado na década anterior. Percebe que agora o momento é outro. Sabe que a radicalização estética de suas propostas, levadas a cabo pela geração do Cinema marginal de forma clandestina e subterrânea, continua. Sabe que a repressão no Brasil é mais violenta que nunca. O contexto histórico brasileiro e mundial eram distintos. O ano de 1968 havia acabado, mas suas rupturas no pensamento e no fazer artístico permaneceriam e iriam se manter ao longo da nova década. Tudo isso fez com que Glauber repensasse o seu cinema e procurasse uma nova forma de arte revolucionária. Ele dirá: "arte revolucionária foi a palavra de ordem no Terceiro Mundo nos anos 60 e continuará a ser nesta década. Acho, porém, que a mudança de muitas condições políticas e mentais exige um desenvolvimento contínuo dos conceitos de arte revolucionaria" (Rocha, 2004, p. 249). Esta nova arte revolucionária teria, necessariamente, que ser constituída por uma estética em que as estruturas do sonho, do inconsciente, da desrazão e do "irracionalismo libertador" fossem emanadas. Na trajetória de Glauber, tal mudança de posição será demarcada pela realização de Cabezas cortadas e pela escrita do manifesto "A estética do sonho", apresentado sob a forma de comunicação na Universidade de Columbia poucos meses após a realização do filme.

Cabezas cortadas será a busca pela materialização dessas novas ideias. Segundo suas palavras: "o que o inconsciente comunica ao consciente em termos de símbolos na experiência individual do sonho pode ser desenvolvido pelo cinema como experiência coletiva" (Gerber, 1982, p.15). O autor acrescenta: "é necessário liberar o inconsciente coletivo em um espetáculo audiovisual integral" (Rocha citado em Avellar, 1995, p. 97). O cinema é sentido como um instrumento de transformação por meio de imagens oníricas e reveladoras, é um fluxo irracional: "você sonha e no sonho vê imagens, coisas que se sucedem. Quando você escreve uma poesia, um conto ou faz um filme, não faz mais que a materialização deste sonho, deste produto do inconsciente que não é controlado pela razão" (Rocha citado em Avellar, 1995, p. 97). As formas e a estrutura do sonho e do delírio compõem o marco delimitador entre esse filme e os anteriores, são a chave da ruptura. Conforme afirmou:

essa vontade de entrar em territórios desconhecidos levou-me a entrar em Cabeças cortadas. Pois se $O$ leão de sete cabeças era um filme feito sobre a exterioridade, em uma tentativa de explicar a história de um ponto de vista materialista, Cabeças cortadas, como o próprio título diz, corta essa tese materialista. É um filme feito sobre o terreno do delírio, na interioridade, 
no território da própria loucura (...). É como se fosse a filmagem de um sonho. Porque Deus e o diabo, Terra em transe e todos esses filmes são a materialização de sonhos culturais; em Cabeças cortadas a matéria é a do inconsciente puro, a fantasmagoria cultural vem em segundo plano, como complemento do fluxo da interiorização. (Pierre, 2003, p. 203)

Esse gesto de cortar o receptáculo da razão e de se instalar no território da loucura será a marca identitária do filme espanhol de Glauber. Cabezas cortadas pode ser entendido como uma anti-continuação de Terra em transe ou uma continuação em zig-zag por sinuosos caminhos que se bifurcam e que nada continuam. Ou, talvez, uma continuação conceitual bastante insólita. Terra em transe terminava com o golpe de Estado perpretado pelo líder autoritário Porfírio Díaz (Paulo Autran), o qual era simbolizado por uma cerimônia de coroamento caótica e convulsiva. Cabezas cortadas se inicia com um velho ex-ditador exilado, no interior de um castelo medieval de algum país europeu. $O$ nome do país de exílio jamais será citado, mas claramente se trata da Espanha. Inclusive, Glauber declarará (Sandroni, 1979a) que o seu protagonista foi diretamente inspirado em ex-ditadores latino-americanos que naquele momento estavam no transcurso de seu exílio espanhol, como o cubano Fulgencio Batista (1901-1973) e o argentino Juan Domingo Perón (1895-1974).

Se no primeiro filme temos o fracasso do populismo e a eclosão das ditaduras militares latino-americanas, no segundo, a narrativa nos convida a compartilhar o cotidiano de um ditador latino-americano deposto. O que há de comum nos dois? O contexto histórico e político da América Latina. Glauber transportará para o seu filme espanhol determinados elementos do filme brasileiro. O nome do ditador será Díaz II (Paco Rabal), o que nos sugere ser o sucessor do golpista de Terra em transe. O nome do país de origem do exilado será Eldorado, o mesmo país fictício do filme de 1967. A diferença é que o Eldorado de Terra em transe era a alegoria da América Latina a partir de um país de fala portuguesa chamado Brasil. O Eldorado de Cabezas cortadas também será uma alegoria do continente, mas assume como base os países da América hispânica. A América Latina é compreendida como uma só, mas essa diferença de ponto de partida será crucial para a linguagem surrealista e simbólica adotada por Cabezas cortadas. É através dessa linguagem que o diretor brasileiro efetivará o seu diálogo audiovisual com a cultura hispano-americana. Sobre Cabezas cortadas Glauber declarou:

o cinema é um instrumento que permite materializar o inconsciente, e é esse inconsciente materializado que aparece na tela. Cabeças cortadas é um filme que deve ser visto através de símbolos e significantes. É um filme estruturalista. Reduzi toda história ao significante. Temos mouros, índios, América Latina colonizada, Espanha moura, encontro de vários mundos (...) cada vez que vejo o filme encontro novas explicações. Há todo um arco de sugestões. Deixei que o trabalho seguisse a estrutura do sonho. (Rocha, 1979, s.p.) 


\section{O SURREALismo de GLAUber Rocha}

É lícito indicar que quando dizemos que Cabezas cortadas adota uma estética "surrealista", não estamos nos referindo ao movimento surrealista capitaneado por André Breton (1896-1966). Glauber vai buscar fontes surrealistas presentes na cultura espanhola e hispano-americana. Ilie ao falar especificamente em um surrealismo espanhol afirmou que o termo surrealista

inicialmente se refere a uma modalidade artística que recebeu seu nome na França, mas que esteve presente em toda a Europa sob muitas formas: pintura, literatura, teatro, balé, música, cinema. Suas raízes [do surrealismo] eram mais culturais e artísticas do que históricas e nacionais. Em outras palavras, suas práticas não surgiram por causa de que determinadas pessoas lançaram uma proclamação em um momento dado da história de uma nação. (Ilie, 1972, p. 15)

Portanto, concordamos que o termo surrealista não é patrimônio exclusivo do movimento francês pelo fato de que ali foi utilizado pela primeira vez. Antes de existir como vocábulo o surrealismo já existia na cultura dos mais diferentes países, e não só nos países europeus. Seguindo a ideia de que a prática surrealista nasceu de tendências irracionais similares na história estética de muitas nações

está claro que assim como os franceses podem ver em Charles Baudelaire (1821-1867) e no Conde de Lautréamont (1846-1870) os antecedentes de seu surrealismo, do mesmo modo os ingleses poderiam reivindicar $\mathrm{Wi}$ Iliam Blake (1757-1827) e William Hogarth (1697-1764), e ainda os espanhóis poderiam alegar Francisco de Quevedo (1580-1645) e Francisco de Goya (1773-1812).(Ilie, 1972, p. 15)

Assim, a erupção de uma estética surrealista espanhola, não se expressará através de um movimento e sim em obras individuais de determinados artistas que apresentam como uma de suas mais importantes bases a tradição irracional do barroco e do grotesco. Cabezas cortadas vai direto nessa base plástica e visual, mas também irá dialogar com ela por meio da mediação de outros artistas, entre eles, o cineasta Luís Buñuel (1900-1983).

A admiração de Glauber por Buñuel já era de longa data. Não vamos nos estender nesta relação'. Aqui, para nossos objetivos, nos cabe apenas indicar que em seu filme Glauber vai sublinhar a filiação com o mestre espanhol. Tentará resgatar um surrealismo cinematográfico considerado "genuíno" através da absorção de L'âge d'or/A idade do ouro (Luís Buñuel, França, 1930), filme com o qual Cabezas cortadas também se conectará pelo uso do mesmo entorno uma vez que escolherá como locação as pedras de Cadaqués, local onde foi filmada a primeira parte do mítico filme de Buñuel. O cineasta brasileiro afirma que desejou continuar uma tradição ao mesmo tempo iniciada e encerrada

\footnotetext{
' Um estudo mais detalhado sobre a relação entre Glauber e Buñuel pode ser encontrado em Garcia (2010).
} 
por A idade de ouro (Sandroni, 1979). Outra aproximação se concretiza pela escolha de atores notadamente buñuelianos. Glauber escalará Paco Rabal² (1926-2001) para interpretar Díaz II e Pierre Clémenti³ (1942-1999) para encarnar o mítico e misterioso Pastor.

O surrealismo de Buñuel será por Glauber elogiado justamente por se distanciar das linhas propostas pelo movimento francês. O entendimento do surrealismo buñueliano por Glauber compartilha uma ideia corrente, defendida por um determinado setor da crítica, de que o cineasta espanhol apresenta uma leitura muito própria e característica do surrealismo. Glauber reitera que Buñuel conheceu Breton depois de Un chien andalou/ Um cão andaluz (França, 1927) e que nunca foi porta-voz das ideias gerais do grupo. A independência do diretor é enfatizada: Buñuel sim seria um surrealista, porém um surrealista particular, desvinculado de grupos ou confrarias. A peculiaridade do surrealismo de Buñuel, como também indicou Bazin4, residiria precisamente no fato que aonde ele vá, levará consigo sua cultura e filtrará através dela seu surrealismo. Glauber afirma que:

de Un chien andalou a El angél exterminador, Buñuel usou o cinema para enfrentar os seus personagens na inconsciência deles mesmos; o homem nu e pelo avesso; justamente por isto Buñuel permanece ainda um surrealista como Dalí (com quem rompeu, acusando-o de servidor ao gosto fácil da burguesia), mas lógico até onde pode ser: a mise-en-scène do imprevisto - sempre na direção do mistério, contudo ligada ao ritmo, à plástica e à literatura espanhola: no México de Nazarín está reconstituída a Espanha, nas marcas da arquitetura colonial e no texto diretamente influenciado por Lorca; as imagens da água, da lua e de anjos sensuais permanecem de Un chien andalou a El Angel exterminador; mesmo negando os quadros insólitos, Buñuel trabalha com Goya e Miró. (Rocha, 2006, p. 176)

Se Buñuel constrói o seu surrealismo a partir de sua cultura, Glauber relaciona a linguagem surrealista adotada em Cabezas Cortadas diretamente ao lugar onde o filme foi realizado. O cineasta construiu a visualidade e a sensorialidade de seu filme a partir de elementos, sonoridades, iconografias e símbolos necessariamente hispanos e hispano-americanos. Como já mencionamos, Cabezas cortadas apresenta como protagonista Díaz II, ex-ditador do fictício país latino-americano Eldorado, no momento de seu exílio espanhol. E aqui, o diretor dialoga com romances que gravitavam em torno de regimes ditatoriais: Tirano Banderas (1924) do espanhol Ramón Del Valle Inclán (1866-1936); El señor presidente (1946) do guatemalteco Miguel Ángel Asturias (1899-1974) e La fiesta del rey Acab (1959) do chileno Enrique Laforcade (1927). Apesar de ter sido filmado antes,

\footnotetext{
${ }^{2}$ Atuou em Nazarín (México, 1958), Viridiana (Espanha, México, 1961) e Belle de jour/A bela da tarde (França, 1967).

${ }^{3}$ Atuou em Belle de jour/ A bela da tarde (França, 1967) e La voie lactée/Via láctea (França, 1969).

4 "Para além das influências acidentais (e sem dúvida felizes e enriquecedoras) toda uma tradição espanhola se conjuga, em Buñuel, com o surrealismo. Essa fixação pelo horrível, esse sentido da crueldade, essa busca dos aspectos extremos do homem, é também herança de Goya, de Zurbarán, de Ribera, de todo um sentido trágico do ser humano que esses pintores manifestaram precisamente na expressão da mais extrema decadência humana: a guerra, a doença, a miséria e seus apodrecimentos" (Bazin, 1977, p. 74).
} 
Cabezas cortadas se aproxima mais confortavelmente em termos estilísticos de romances do chamado boom literário latino-americano que tiveram ditadores como protagonistas: El recurso del método (1974) do cubano Alejo Carpentier (1904-1980); Yo el supremo (1974) do paraguaio Augusto Roa Bastos (1917-2005) e El otoño del patriarca do colombiano Gabriel García Márquez (1927-2014). Esses três últimos, além de terem ditadores como protagonistas, abordam o absurdo, o grotesco, a farsa e a memória, tal como o filme de Glauber.

Em Cabezas cortadas a presença física do ditador e, por conseguinte, de sua memória e imaginário, na velha Espanha, aciona uma complexa rede de referências. $\mathrm{O}$ absurdo da história e da realidade latino-americana está presente em Díaz II. Glauber afirmou que dificilmente poderia ter dirigido Cabezas cortadas em outro país europeu, isto é, articulando outras referências culturais, e assim destaca o caráter originalmente surrealista do continente latino-americano:

Ricardo Muñoz [Suay] e Pere Fages me convidaram a fazer um filme na Espanha, então me veio a idéia de fazer Cabeças cortadas. Culturalmente, a Espanha é muito parecida com a América Latina e também o Brasil, mesmo que na Espanha não existam negros. Acho que Cabeças cortadas é um filme espanhol. Provavelmente, de fato em outro país europeu não teria podido inventar as mesmas imagens e montar estas imagens com os mesmos sons. $O$ aspecto figurativo do filme é diretamente inspirado na tradição popular - isto teria sido provavelmente impossível nos países europeus desenvolvidos e industrializados, aonde a presença da arte popular camponesa foi absorvida pela sociedade de consumo. (Sandroni, 1979, p. 2)

Glauber busca a Espanha na América Latina e a América Latina na Espanha. Para o realizador baiano, a realidade do continente latino-americano é essencialmente mágica e convulsiva. Nossa realidade histórica e cotidianidade se localizaria em uma supra-realidade. Esta perspectiva teve a sua origem, não no cinema e sim na literatura. Apesar de existir um precursor menos conhecido e citado ${ }^{5}$, essa interpretação foi difundida mundialmente por sua sistematização encontrada no prólogo a El reino de este mundo (1949) de Alejo Carpentier, em que o escritor e musicólogo cubano expõe sua teoria do "Real Maravilhoso Americano" e localiza o "maravilhoso" como componente da realidade americana. Carpentier enxerga a América como uma entidade cultural possuidora de traços singulares, originados por sua peculiar formação étnica e histórica. Esses traços justificariam a não separação entre o real e o maravilhoso. O escritor, ao redefinir o conceito de supra-realidade, busca não confundi-lo como um produto da fantasia e sim

\footnotetext{
${ }^{5} \mathrm{~A}$ atribuição do maravilhoso ao mundo americano teve, no século XX, pelo menos um precursor anterior a Carpentier. Trata-se do escritor chileno Francisco Contreras [1877-1933]. Segundo nos conta Irlemar Chiampi (1983), no Proêmio ao seu El pueblo maravilloso (1927) Contreras chama a atenção pela sua defesa do primitivismo, da mestiçagem e das mitologias da América. Muito atento às manifestações folclóricas dos povos latino-americanos, e influenciado pelas teorias freudianas, Contreras lhes atribuiu uma mentalidade mítica, porque, segundo ele, teriam uma intuição muito lúcida do maravilhoso, do dom de encontrar vínculos mais ou menos figurados com o desconhecido, com o misterioso e com o infinito. Para o autor nossa mitologia se configurava como elemento essencial e precioso de nosso espírito coletivo.
} 
concebê-lo como uma esfera fundida à realidade empírica e ordinária. A América buscada é uma América ainda não contaminada pela reflexividade, trata-se de um caldeirão de religiosidade e de mitos primitivos, aptos em concretizar o projeto poético do Real Maravilhoso. Carpentier afirma que "pela virgindade da paisagem, pela formação, pela ontologia, pela presença fáustica do índio e do negro, pela revolução que constituiu seu recente descobrimento, pelas fecundas mestiçagens que propiciou, a América está muito longe de ter esgotado seu caudal de mitologias" (Carpentier, 2004, p. 14).

Não vamos analisar o famoso prólogo/ manifesto de Carpentier e tampouco entrar nos detalhes de sua ruptura com o movimento surrealista ${ }^{6}$. Para os propósitos deste artigo nos basta apenas mencionar a proximidade artístico-conceitual de Glauber com os postulados defendidos por Carpentier e detectar suas diferenças. Uma das que nos parecem fundamentais reside no fato de que para Glauber a supra-realidade da América não está somente em nossas raízes afro-indígenas e nas mitologias nativas como também na herança deixada pelo colonizador. O surrealismo da América não é só intrínseco e interno como também externo. É um elemento presente no conquistador ibérico. $O$ colonizador é tão surrealista como os colonizados. Glauber, a partir dessa ideia, concebe o mosaico referencial e estético de Cabezas cortadas absorvendo tanto símbolos hispanos como hispano-americanos. Como Carpentier, Glauber assimila a História e a expressa em suas criações. O surrealismo de Glauber é determinado pela cultura e pela História do ambiente de produção de seus filmes. Portanto, o cineasta brasileiro absorve as formas, a paisagem, o som e a atmosfera do ambiente em que está trabalhando e os reconfigura esteticamente. Para o diretor é necessário que haja uma aproximação cultural e histórica entre ele e o lugar da realização de seus filmes.

Para o acionamento dessa aproximação, Cabezas cortadas escolherá o elemento musical como uma das principais vias de acesso ao vasto mundo cultural hispano-americano. Glauber havia declarado que "é na música popular onde você encontra a autêntica história e sociologia do país onde você filma" (Vila-Matas, 1970, s.p.). A música, definida por muitos como a arte mais "pura", "subjetiva" e "abstrata" entre todas as artes, não será por coincidência uma das chaves para a composição de Cabezas cortadas. Glauber a maneja tendo em mente dois conceitos, o primeiro é a consciência da música como expressão da sensibilidade popular e como índice da identidade de um povo. Neste sentido, a música seria o desdobramento e a expressão de um determinado contexto histórico e sócio-cultural concreto. O segundo conceito, não exclui o primeiro, mas o complementa e o transcende. Trata-se da música como linguagem sagrada de organização do mundo. A música como princípio criador e transformador dos seres e

\footnotetext{
${ }^{6}$ Sobre Carpentier e o movimento surrealista ver Monegal (1971).

7 Talvez seja por isso que ao ser questionado no Festival de Cannes de 1969 se rodaria um filme fora do Brasil, Glauber tenha respondido "na Europa jamais faria um filme; os únicos lugares em que filmaria seria na Espanha, em Portugal ou na África. No resto da Europa jamais; aqui não se pode fazer nada" (Martínez Torres, 1970, p. 69). Em 1975 o diretor filmou Claro na Itália, país em que se sentia bastante confortável. Sabe-se também que ao longo de sua trajetória tentou filmar o roteiro de América Nuestra em diversos países da América Latina e que em 1975 tentou realizar o projeto do que seria o seu último filme, A idade da Terra, no México. Em 1974, em Portugal, colabora na realização do filme coletivo As armas $e$ o povo, sobre a Revolução dos Cravos. Em 1980, após o fracasso de A idade da terra, parte para um novo exílio, dessa vez em Sintra, Portugal.
} 
das coisas, a música como ritual, a música como elemento místico-sagrado. Em outras palavras, a música é ao mesmo tempo uma expressão física e metafísica, um fenômeno feito de matéria e não-matéria, corpo e espírito. Glauber não separa esses conceitos e sim os funde e os transforma em somente um. A mística está na História e a História está na mística. Assim, a sonoridade da América Latina é captada sem haver delimitação entre uma e outra.

A América Latina é, através da música, interpretada como uma entidade unitária. A música é o agente promotor dessa unidade. Portanto, é uma unidade não só cultural como também espiritual. Em Cabezas cortadas o fenômeno denominado América Latina transborda a esfera terrestre e se torna uma maneira de sentir o mundo ou um modo perceptivo de compreensão do mundo. A música é a chave para essa compreensão, uma vez que é através dela que lemos o mundo e que nos amalgamamos com ele. Ao se constituir como essência de nossa subjetividade e magia, a música da América Latina é uma só, todas as tradições sonoras se metamorfoseiam em uma. Desse modo escutamos em Cabezas cortadas ritmos afro-cubanos, rumbas, tangos, boleros, rancheras e também coblas catalãs, flamencos, músicas medievais e renascentistas espanholas. Todas essas musicalidades são fervidas em um mesmo caldeirão até formar um único caldo sonoro. A nossa originalidade estaria nesse caldo borbulhante.

Isso quer dizer que Glauber, como Carpentier, sublinha a idiosincrasia latino-americana frente aos padrões europeus. Entretanto, a visão do europeu diante da América não é totalmente recusada uma vez que tanto o cineasta como o escritor admitem que - olhar externo sobre a América contribui para a formação do nosso próprio olhar. Em Cabezas Cortadas há uma cena que traduz essa ideia mítica da América, fundada pelos primeiros cronistas do Novo Mundo, e perpetuada em grande parte pela arte latino-americana. Em uma taberna em que músicos estão tocando ritmos afrocubanos, um homem encara a câmera e diz "naquelas distantes e alheias terras da América, existem pássaros de cores diferentes e animais míticos fabulosos como o carcará e o boto, o dragão de São Jorge, a serpente de sete cabeças. E a terra foi descoberta por Francisco de Orellana, que a chamou Amazônia e nela vivem lindas mulheres guerreiras". Esse deslumbramento diante da natureza e da mestiçagem americanas é compartilhado por nós, nativos do continente, e ao mesmo tempo integra a nossa necessidade em enfatizar que somos diferentes.

\section{HistórIA E SONHO}

Se em Cabezas cortadas essa nossa diferença se estabelece a partir do próprio "nascimento" da América, resulta interessante ver como o diretor interpretou a História em seu filme. Em Cabezas cortadas a História se expressa prioritariamente através de símbolos e esses símbolos são onipresentes nos delírios de Díaz. A visão da História de Eldorado muitas vezes se confunde com a subjetividade do próprio ditador. O segmento onde vemos a representação da Conquista da América, por exemplo, foi interpretado por determinados críticos como "os sonhos de Díaz". Na verdade, não só essa sequência 
em particular, e sim praticamente todas as cenas de Cabezas cortadas foram interpretadas pela maior parte dos analistas do filme como os sonhos do ditador. Claudio Vallentinetti, por exemplo, definiu as duas cenas da chamada telefônica do personagem como as únicas cenas "reais" do filme (Vallentinetti, 2002, p. 139). De maneira breve o autor menciona uma possível relação entre esse procedimento em Cabezas cortadas e o flashback de Terra en transe. De fato, é possível afirmar que entre a primeira e a última cena de Terra em transe existe um longo flashback, que é o delírio do poeta Paulo Martins agonizante no momento de sua morte. Mas, em Cabezas cortadas ocorre uma diferente estrutura. Se a atmosfera de delírio é onipresente no filme, nem todos os delírios provêm da mente de Díaz. Diferentemente de Terra em transe, Cabezas cortadas não é um longo flashback de seu protagonista. Porém, como nos indicou Cardoso (2007, p. 102), a ausência de dados narrativos claros e a inverosimillhança das situações que se impõem podem, no começo, nos conduzir a uma adesão ao ponto de vista do ditador. Assistindo ao filme podemos ter a sensação de que estamos assistindo os delírios de um ditador no exílio. Realmente, a quase onipresença de Díaz em Cabezas cortadas (ele aparece na maior parte das cenas) e a analogia entre a sua loucura e a aparente falta de lógica do filme pode nos levar a essa interpretação de que o filme é a expressão de sua mente. Além disso, a leitura de que a diegese se trata de um pesadelo ou uma alucinação do protagonista explicaria de maneira racional as elipses temporais (como a elipse da cena da História de Eldorado), a autonomia das sequências, a ausência de continuidade cronológica e espacial, o inverossímel das situações e a abundância de símbolos. Se todo o filme é um sonho de Díaz, tudo estaria muito bem explicado e justificado.

Cremos que o filme não é um sonho ou uma alucinação de Díaz II. Não pensamos, como sugeriu Valentinetti, que o filme trabalhe com a divisão entre o plano real e o plano onírico. Essa separação bem marcada entre a esfera do mundo real (as duas chamadas telefônicas dentro do castelo medieval) e a esfera do mundo dos sonhos (as demais cenas) nos parece muito anti-surrealista. Não interpretamos as duas cenas das

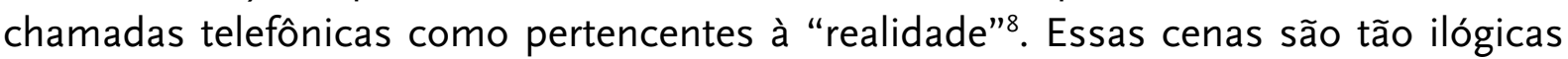
como as demais. Concordamos com Cardoso (2007, p. 102) quando afirma que o filme não ocorre dentro da mente do protagonista apesar de formalizar determinados processos mentais frequentes no sonho. Processos mentais como a condensação de objetos e símbolos, os aspectos compensatórios não encontrados na realidade (a conquista de Eldorado revivida) e a disolução entre as marcas temporais (entre passado, presente e futuro) aparecem ao longo do filme. Não há dúvida de que o fato de reproduzir processos mentais oníricos não necesariamente faz que a representação seja definida como originária de uma situação onírica. A situação de Cabezas cortadas não é onírica, mas sua estrutura e lógica sim.

Cabezas cortadas, à sua maneira, põe em prática um conceito já articulado pelo cinema surrealista dos anos 1920: a total convergência entre material onírico e material cinematográfico. A natureza da imagem cinematográfica é compreendida como

${ }^{8}$ A definição dessas cenas como as únicas cenas "reais" de Cabezas cortadas também aparece em Gardies (1977) e em Bamonte (2002). 
ontologicamente onírica. A estrutura de um filme deve ser similar à estrutura de um sonho. O cinema não deve imitar a realidade ordinária, não deve mimetizá-la porque assim estaria sendo contra a sua essência e a sua autêntica realidade: a realidade dos sonhos. Buñuel, na sua conferência "O cinema: instrumento de poesia" retoma uma ideia difundida pelo primeiro André Breton ao afirmar que "o mais admirável no fantástico é que o fantástico não existe, tudo é real" (Buñuel, 2000, p. 68). Isto é, não há uma linha divisória entre loucura e razão, entre sonho e realidade, entre o consciente e o inconsciente. Essas duas realidades se fundem inaugurando uma realidade outra, uma supra-realidade. Trata-se do aproveitamento do aspecto ilógico, surgido do subconsciente, do sonho, do fortuito e das associações imprevistas que, também sendo uma realidade, se fundem com a realidade concreta, pautada pela razão e pela lógica, em busca da harmonia conciliadora dos contrários.

Portanto, vemos na estrutura de Cabezas cortadas uma tentativa de reproduzir a estrutura da mente em estado onírico. Cabezas cortadas segue as formas do sonho mas não elabora a representação diegética de um sonho. Uma possível exceção poderia ser, justamente, a cena da conquista de Eldorado, entretanto até aqui não há elementos suficientes para defini-la categoricamente como tal. A possibilidade de que essa cena seja a representação de um sonho é somente sugerida e isso lhe confere um caráter ambíguo. Não recusamos totalmente a hipótese de que o segmento pertença aos sonhos do personagem principal, mas sugerimos novos caminhos interpretativos. Entendemos que para além de ser um delírio ou um sonho de Díaz II, esse segmento representa a História e esta não é fruto da mente de um único homem. As imagens da conquista de Eldorado podem ser a representação de um sonho de Díaz, porém não é só um sonho individual. Mais do que ser unicamente a interpretação onírica do ditador sobre a História (uma História em que ele e seus antepassados são personagens), o que vemos é um comentário da instância enunciativa. É o discurso exposto no filme que nos apresenta sua interpretação da História da América. E este discurso é proferido por meio de uma forma sumamente alegórica. Portanto, a interpretação alegórica da História não poderia pertencer ao mesmo plano das sequências anteriores. A História é passado mas também é atemporal no sentido que também é mito. História da América e mito da América aqui se confundem. Sendo narrada de forma alegórica, a História não é um "acontecimento do passado" e sim um delírio coletivo. A narrativa de Cabezas cortadas, portanto, abre um parêntese para a exposição de sua visão da História. Vamos a ela.

Neste conjunto de cenas que compreendemos como a representação da Conquista da América/ Eldorado presenciamos essa armação alegórica em que é detonado o espetáculo da dominação. Nele, a dominação é representada por um único homem/ arquétipo: o colonizador. Tal colonizador é Díaz, um típico criollo. Um governante nascido na América que perpetua os ritos opressivos de seus antepassados. Outra característica deste espetáculo da opressão é a divisão estrutural da dominação em diferentes fases e em cada uma delas vemos a inclusão de mais um personagem no jogo da História.

$\mathrm{Na}$ primeira cena dessa série ou segmento, dois cavaleiros medievais cavalgam, e por um momento, interrompem a cavalgada e param diante da câmera. Díaz entra em 
quadro, pega o cavalo que está entre os cavaleiros, o monta e cavalga. Os dois cavaleiros seguem atrás, são seus seguidores, estão a serviço do poder. Essa ação, enquadrada em um plano de conjunto estático e com uma música sacra-medieval na banda sonora, nos oferece o sentido da alegoria: o que vemos é una cerimônia, um ato solene. $\mathrm{Na}$ cena seguinte um índio caminha, a câmera segue seu movimento lateralmente, quando ele para, a câmera também se detém. Surgem os três cavaleiros (Díaz e seus servos) descendo um morro. O Índio está em frente aos cavaleiros e de costas para a câmera. Se inicia uma coreografía entre os personagens, uma dança constituída de resistência e ataque. O Índio se distancia de seus opressores e se posiciona no centro do quadro. Nesse momento, retira um objeto do bolso e o mantém em suas mãos, se trata de uma caixa. Díaz II se aproxima e lhe toma a caixa. O Índio corre para recuperar o objeto e a coreografía recomença. O oprimido se põe de joelhos e cai no chão. Os opressores circulam a cavalo ao redor de seu corpo. Na cena seguinte o Índio já está convertido em servo, entretanto, se trata de um servo inferior se o comparamos com os demais. Ele camina a pé escoltando os seus superiores. Caminhando sozinho, o Índio encontra um mouro dando marteladas em uma pedra. Tenta aprisioná-lo. Eles lutam, o ditador entra em quadro e circula ao redor dos dois homens. O Índio toma o martelo das mãos do mouro e o entrega a Díaz. O ditador o ergue como uma lança e como o sinal de mais uma vitória. Em seguida, entram em quadro os dois cavaleiros e despois o Índio e o Mouro, já integrado ao grupo. Percebemos que mais que individualidades os personagens representam atores históricos. São personagens símbolos, o Índio não é só um índio e sim todos os índios. O mesmo se pode dizer do Mouro e dos dois cavaleiros sem rosto. Eles representam uma entidade, uma coletividade ${ }^{9}$. O colonizador os cooptou, os convenceu, pela força, em servi-lo. No próximo plano aparece o lado oposto, os elementos que se opõem a esse poder. Trata-se de camponeses armados. A câmera os descreve detalhadamente seguindo o movimento do caminhão em que eles se encontram. Aqui constatamos claramente a existência de dois extremos: o povo que foi submetido e o povo que se rebela. Vemos como a América se formou e como poderá ser transformada.

\section{CONSIDERAÇÕES FINAIS}

Há ainda, no filme, uma segunda exposição da História da América/Eldorado. É a mesma História, só que contada de forma distinta. Agora, ela será narrada pela voz do próprio diretor de Cabezas cortadas. $\mathrm{O}$ aspecto grotesco, patético e cômico do ditador se expande nessa sequência. O personagem está na lama brincando com diversos objetos enquanto escutamos em over a narração de Glauber, que nos conta ao mesmo tempo a História de Eldorado e a biografía do ditador. Sobreposta ao over escutamos uma música de tonalidades cômicas. O fato de Glauber ser o narrador é curioso não só porque ele é o autor do filme, mas também pela indicação explícita de sua origem. O filme é a visão de um latino-americano de origem lusitana sobre a América de origem hispana, logo a

9 Por essa razão, o autor utiliza letras maiúsculas na designação Índio e Mouro. No roteiro do filme, publicado no livro Roteiros do tercepro mundo (Rocha, 1985), o realizador utiliza as mesmas designações. 
operação efetivada por Glauber em assumir a narração em espanhol evidenciando seu sotaque brasileiro parece ser estratégica. Esse procedimento destaca a especificidade de seu olhar e a singular interpretação da América presente em Cabezas cortadas. Além de enfatizar que, apesar da diferença idiomática, o Brasil é tão latino-americano como os países de fala hispânica. Independente do idioma, a América Latina é uma só e isso parece evidente na História de Eldorado. Glauber a constrói misturando muitos elementos da História do Brasil com os da América hispânica. Transcreveremos parte da narração over:

nas páginas da História, Eldorado foi descoberto no século XVI por navegantes espanhóis e se desenvolveu inicialmente graças ao cultivo da cana de açúcar. Alguns anos mais tarde chegaram os escravos negros da África e o vice rei de então construiu estradas, um novo porto e conquistou o território de Alecrim exterminando completamente a civilização indígena local. Os colonizadores começaram a criar gado e a plantar café e foi dessa situação econômica que surgiram os primeiros sintomas nacionalistas. As rebeliões contra a Coroa espanhola foram violentamente reprimidas e todos os líderes foram enforcados e esquartejados em praça pública. Séculos mais tarde surgiram os primeiros libertadores. Emmanuel Díaz, advogado muito inteligente, influenciado pela revolução francesa e pelas ideias da nova república americana, organizou a Sociedade Secreta pela Libertação de Eldorado. A ideia incendiou as plantações e, dez anos mais tarde, Eldorado se proclamava monarquia independente. Emmanuel Díaz colocou a coroa sobre sua própria cabeça e desde então todos os seus descendentes continuaram a sucessão do poder. Quando ocorreu a revolução republicana de 1910, toda a dinastia Díaz foi passada por armas e nosso herói escapou graças a ajuda de um velho criado negro. Não tomou a vingança do povo como lição. Exilado na Europa, estudou direito e filosofia até voltar ao seu país como líder de um golpe de Estado organizado pela Companhia de Exportações Internacionais, a EXPRIN. Foi recepcionado por seu amigo e protetor William Bradley, um milionário da Califórnia. Desde então, Díaz subiu ao poder várias vezes e várias vezes foi deposto e várias vezes voltou e voltará.

Glauber começa a narração over com "nas páginas da História" sublinhando a existência de uma História oficial, de uma História escrita por alguém que certamente pertence ao lado dos "vencedores". A descrição da História de Eldorado, de fato, soa bastante escolar, como se tivesse sido extraída de um livro didático. Essa descrição básica é bastante irônica, apesar do tom formal do narrador, e nos indica fatos que podem ser encontrados na História da maior parte dos países do continente. A iniciação de uma economia agrária dirigida à exportação para a metrópole, o extermínio dos índios, o uso de mão de obra escrava africana, o desenvolvimento econômico como motor do desejo de separação por parte da elite local, a ilustração dos libertadores americanos realizada na Europa, a influência do pensamento racional iluminista nas guerras de 
independência. Fatos que podem simplificar a História de todos os países latino-americanos em uma só História. Isso, além de comprovar nosso passado histórico comum, comprova o estado de nosso presente e de nosso provável futuro. A infinita ida e vinda de Díaz ao poder metaforiza uma certa imobilidade histórica. O poder está sempre nas mãos dos mesmos governantes, a roda da História latino-americana, até o momento, parece sempre estar voltando para o mesmo lugar. Díaz II chafurda na lama.

Tivemos como proposta, neste breve ensaio, analisar alguns aspectos de Cabezas cortadas referentes ao seu diálogo com a cultura hispano-americana e à sua ideia de identidade latino-americana. Percebe-se que a procura pela compreensão dessa identidade não se dá mais pelas vias da razão ou pelo entendimento de identidade articulado pelo cinema político latino-americano dos anos 1960. Há neste filme de Glauber uma ideia renovada de arte revolucionária e distintas proposições em relação ao binômio arte/política consonantes com o que foi fecundado a partir de 1968. Glauber, aqui, se arrisca e expõe sua resposta às mudanças das condições políticas e mentais que o mundo experimentou desde então.

\section{REFERÊNCIAS}

Avellar, J. C. (1995). A ponte clandestina: Birri, Glauber, Solanas, Getino, García Espinosa, Sanijés, Alea - Teorias de cinema na América Latina. Rio de Janeiro / São Paulo: Ed.34, Edusp.

Bamonte, D. (2002). Afinidades eletivas: o diálogo de Glauber Rocha com Pier Paolo Pasolini (1970-1975). Doutorado em Comunicação e Audiovisual, Escola de Comunicações e Artes, Universidade de São Paulo, São Paulo.

Bazin, A. (1977). El cine de la crueldad, de Buñuel a Hitchock. Bilbao: Ediciones Mensajero.

Bentes, I. (Ed.) (1997). Cartas ao mundo. São Paulo: Companhia das letras.

Buñuel, L. (2000). Escritos de Luis Buñuel. Madrid: Editorial Páginas de Espuma.

Cardoso, M. (2007). O cinema tricontinental de Glauber Rocha: política, estética e revolução (1969-1974). Tese de Doutoramento em História, Faculdade de Filosofia, Letras e Ciências Humanas, Universidade de São Paulo, São Paulo, Brasil.

Carpentier, A. (2004). El reino de este mundo. Madrid: Alianza Editorial.

Chiampi, I. (1983). El realismo maravilloso. Forma e ideologia en la novela hispanoamericana. Caracas: Monte Avila Editores.

Garcia, E. (2010). Estética, magia y revolucion: un estudio comparativo entre Cabezas Cortadas de Glauber Rocha y la Montana Sagrada de Alejandro Jodorowsky. Dissertação de Mestrado em Estudos Cinematográficos, Universidade de Guadalajara, Guadalajara, México.

Gardies, R. (1977). Glauber Rocha, política, mito e linguagem. São Paulo: Paz e terra.

Gerber, R. (1982). O mito da civilização atlântica, Glauber Rocha, cinema, política e estética do inconsciente. Petrópolis: Editora Vozes.

Ilie, P. (1972). Los surrealistas españoles. Madri: Taurus. 
Monegal, E. R (1971). Alejo Carpentier: lo real y lo maravilloso en El reino de este mundo. Iberoamericana, XXXVII(76-77), 619-649. https://doi.org/10.5195/reviberoamer.1971.2875

Pierre, S. (1996). Glauber Rocha. Campinas: Papirus.

Sandroni, C. (1979, 8 de junho). Entrevista e Glauber Rocha, Jornal do Brasil.

Rocha, G. (1985). Roteiros do terceyro mundo. Rio de Janeiro: Alhambra-Embrafilme.

Rocha, G. (1979). Material de divulgação de Cabezas Cortadas. Rio de Janeiro: Embrafilme.

Rocha, G. (2006). O século do cinema. São Paulo: Cosac Naify.

Rocha, G. (2004). Revolução do cinema novo. São Paulo: Cosac Naif.

Torres, A. M. (1970). Glauber Rocha y Cabezas Cortadas. Barcelona: Anagrama.

Valentinetti, C. M. (2002). Glauber, um olhar europeu. São Paulo: Instituto Lina Bo e P.M Bardi.

Vila-Matas, E. (1970). Bocaccio. Barcelona.

\section{NOTA BIOGRÁFICA}

Estevão Garcia é coordenador e professor do curso de Cinema e Audiovisual do Instituto Federal de Goiás (IFG). Doutor em Meios e Processos Audiovisuais pela Escola de Comunicações e Artes (ECA) da Universidade de São Paulo (USP), mestre em Estudos Cinematográficos pela Universidade de Guadalajara (UdG), México, e bacharel em Cinema pela Universidade Federal Fluminense (UFF). Foi professor visitante do curso de Cinema e Audiovisual da Universidade Federal da Integração Latino-Americana (UNILA). Pesquisador atuante em pesquisas e publicações sobre o cinema latino-americano.

Email: estevao.garcia@ifg.edu.br

Morada: Campus Cidade de Goiás do Instituto Federal de Educação, Ciência e Tecnologia de Goiás (IFG). Rua 02, Qd. 10, Lts. 1 a 15, Residencial Bauman, Cidade de Goiás - GO CEP: $76600-000$

* Submetido: 20-06-2018

* Aceite: 03-01-2019 